Bangladesh J. Bot. 43(2): 147-155, 2014 (September)

\title{
EFFECTS OF INTEGRATED NUTRIENT MANAGEMENT ON GROWTH AND YIELD OF MAIZE (ZEA MAYS L.) - GOBHI SARSON (BRASSICA NAPUS L.) CROPPING SYSTEM IN SUB-TROPICAL REGION UNDER FOOTHILLS OF NORTH-WEST HIMALAYAS
}

\author{
Vikas Gupta*, Anil Sharma ${ }^{1}$, Jai kUmar, Vikas Abrol, Brinder Singh \\ AND MAHENDER SINGH \\ AICRP for Dryland Agriculture, DLRSS, Rakh Dhiansar, SKUAST-J, Bari Brahmana, \\ Samba, J\&K 181133, India
}

Key words: Maize, Gobi sarson, Yield, INM, RWUE, HUE

\begin{abstract}
A pronounced residual effect of organic and inorganic fertilizers, applied in maize crop was observed on yields of maize-gobhi sarson cropping system. The experiment was conducted with 10 treatments of N, P, K, FYM, crop residue and zinc sulphate nutrients. The highest growth, yield and yield components of maize crop were recorded with $100 \%$ recommended fertilizer dose-RFD $+\mathrm{ZnSO}_{4} 20 \mathrm{~kg} / \mathrm{ha}$ and the grain yield $(2409 \mathrm{~kg} / \mathrm{ha})$ was about $101 \%$ higher over the control. In case of gobhi sarson, the highest seed yield (1081 $\mathrm{kg} / \mathrm{ha}$ ) was observed as a pronounced residual effect of $10 \mathrm{t} / \mathrm{ha}$ FYM in preceding maize crop; which was about $81 \%$ higher over the control. The treatments where $50 \% \mathrm{~N}$ was substituted by FYM and crop residue in maize crop had the best reflection in enhancing the seed yield of gobhi sarson to the tune of 74 and $70 \%$ over the control and 16 and 13\% over farmer's practice. The highest rain water use efficiency (RWUE) and heatuse efficiency (HUE) was recorded in treatment $100 \% \mathrm{RFD}+\mathrm{ZnSO}_{4} 20 \mathrm{~kg} / \mathrm{ha}$ in maize crop and $10 \mathrm{t} / \mathrm{ha}$ FYM in gobhi sarson.
\end{abstract}

\section{Introduction}

Rapeseed-mustard is grown on an area of 5.53 mha with production and productivity of 6.41 $\mathrm{mt}$ and $1157 \mathrm{~kg} / \mathrm{ha}$, respectively in India (Anon. 2010). About 12\% of the total area of Jammu region constituting dry semi-hilly belt is rainfed in nature, the most stressed ecosystem of this region and is locally known as kandi area (Abrol et al. 2007). Maize-wheat is the most prevalent cropping sequence being practiced by farming community of kandi belt in Jammu (under rainfed conditions). Gobhi sarson crop has emerged as potential replacement for wheat as this crop has wider adaptability and could suitably exploit residual moisture of rainy season. Heat use efficiency (HUE), i.e., efficiency of utilization of heat in terms of dry matter accumulation is an important aspect, which has practical utility as reported for soybean and pigeonpea (Balakrishanan and Natarajaratnam 1986). Rao et al. (1999) reported that the total heat energy available to any crop is never completely converted to dry matter even under the most favourable agroclimatic conditions.

Increase in productivity of maize-based cropping system with integrated use of farmyard manure and chemical fertilizer has been widely reported (Kumpawat 2004, Jamwal 2005). As both the crops are highly exhaustive and thus fertility of the soil is depleted due to the presently lower quantity of fertilizer application by farmers of kandi region. In general, scheduling of fertilizers is based on the individual nutrient requirement of the crop and the carry over effect of manure and fertilizer applied to preceding crop is ignored (Panwar 2008). In sub-tropical kandi belt, generally organic manures like FYM, crop residues, or green manuring etc are applied to the crops in kharif season due to the availability of adequate amount of moisture as during rabi season moisture is the main limiting factor due to almost negligible rainfall in October-December months. Judicious use

*Author for correspondence: < vikasadr@gmail.com>, ${ }^{1}$ Central Institute of Temperate Horticulture, Rangreth, Srinagar, J\&K 190007, India. 
of organic matter can stabilize the productivity and sustainability of maize-gobhi sarson system. Since the information on this aspect is lacking in the region, the present study was initiated to assess the appropriate (organic and inorganic) nutrient management for maize-gobhi sarson cropping system.

\section{Materials and Methods}

Experiments were performed at Research farm, DLRSS, Rakh Dhiansar, SKUAST-J, Jammu and Kashmir state (32 $39^{\circ} \mathrm{N} 74^{\circ}$ 53" E $332 \mathrm{~m}$ amsl), India in kharif (June - September) and rabi (October - March) seasons of 2006-07, 2007-08 and 2008-09 under rainfed conditions. The soil of the experimental site was sandy loam having low available N (110 to $209 \mathrm{~kg} / \mathrm{ha}$ ), P (12 to 16 $\mathrm{kg} / \mathrm{ha}$ ), $\mathrm{K}\left(106\right.$ to $180 \mathrm{~kg} / \mathrm{ha}$ ) and $\mathrm{pH} 6.8$ to 7.2 . The treatments comprised of $\mathrm{T}_{1}$ : Control; $\mathrm{T}_{2}: 100$ $\%$ recommended fertilizer dose-RFD (60:40:20 NPK kg/ha); $\mathrm{T}_{3}: 50 \% \mathrm{RFD} \mathrm{T}_{4}: 50 \% \mathrm{~N}$ (crop residue); $\mathrm{T}_{5}: 50 \% \mathrm{~N}(\mathrm{FYM}) ; \mathrm{T}_{6}: 50 \% \mathrm{RFD}+50 \% \mathrm{~N}$ (crop residues); $\mathrm{T}_{7}: 50 \% \mathrm{RFD}+50 \% \mathrm{~N}$ (FYM); $\mathrm{T}_{8}: \mathrm{FYM} 10 \mathrm{t} / \mathrm{ha} ; \mathrm{T}_{9}: 100 \% \mathrm{RFD}+\mathrm{ZnSO}_{4} 20 \mathrm{~kg} /$ ha and $\mathrm{T}_{10}:$ Farmers practice $(\mathrm{FYM} 4$ $\mathrm{t} / \mathrm{ha}+$ urea $40 \mathrm{~kg} / \mathrm{ha}$ ). Maize (var. Mansar) was sown on 29 June, 2 July and 29 June and harvested on 24 September, 1 October and 26 September for the kharif seasons of 2006, 2007 and 2008 , respectively. Whereas, gobhi sarson (var. DGS-1) was sown on 14, 16 and 16 October and harvested on 9, 11 and 1 April for the rabi seasons of 2006-07, 2007-08 and 2008-09, respectively. Maize and gobhi sarson crops were sown in lines in a unit plot size of $6 \mathrm{~m} \times 4 \mathrm{~m}$ with a spacing of $60 \mathrm{~cm} \times 20 \mathrm{~cm}$ and $30 \mathrm{~cm} \times 20 \mathrm{~cm}$, respectively. All the treatments were applied in maize crop and the left over effects were studied in gobhi sarson crop. A total rainfall of 630.0, 859.8 and $692.1 \mathrm{~mm}$ in 24, 32 and 28 rainy days was received during kharif and 308.8, 175.0 and $110.4 \mathrm{~mm}$ in 18,11 and 15 rainy days during rabi in the respective years of cultivation. Urea, diammonium phosphate, muriate of potash and gypsum were used as a source of nitrogen, phosphorus, potassium and sulphur, respectively. Maize equivalent yield (MEY) was computed by converting the gobhi sarson yield into the yield of maize on the basis of the prevailing market prices of individual crop. Weather data was recorded at Meterological Observatory, DLRSS, Rakh Dhiansar and the following agro-meteorological indices were calculated:

(a) Accumulated heat unit $\left(\sum H U\right)$ : The accumulated heat units were calculated by adopting the formula given by Nuttonson 1955 .

$$
\mathrm{HU}=\frac{\sum_{\mathrm{a}}^{\mathrm{b}}[\mathrm{T} \max +\mathrm{T} \min ]-\mathrm{T}_{\mathrm{b}}}{2}
$$

where, $\mathrm{T} \max =$ Maximum temperature $\left({ }^{\circ} \mathrm{C}\right)$ during a day; $\mathrm{T} \min =$ Minimum temperature $\left({ }^{\circ} \mathrm{C}\right)$ during a day and $\mathrm{T}_{\mathrm{b}}=$ Base temperature 8 and $5^{\circ} \mathrm{C}$ for maize and gobi sarson crops, respectively under sub tropical conditions

a starting date of phenophase of interest; $b$ ending date of phenophase of interest.

(b) Heat use efficiency (HUE): HUE is the ratio of dry matter $(\mathrm{kg} / \mathrm{ha})$ to the cumulative heat unit to attain the phenophases.

$$
\operatorname{HUE}\left(\mathrm{kg} / \mathrm{ha} /{ }^{\circ} \mathrm{C} / \text { day }\right)=\frac{\text { Dry matter }(\mathrm{kg} / \mathrm{ha})}{\text { Cumulative heat unit }\left({ }^{\circ} \mathrm{C} \text { days }\right)}
$$

The statistical analysis was done by using SPSS16 and OPSTAT software. 


\section{Results and Discussion}

Recommended fertilizer dose (100\% RFD) along with $\mathrm{ZnSO}_{4} 20 \mathrm{~kg} / \mathrm{ha}\left(\mathrm{T}_{9}\right)$ in kharif season recorded statistically highest all growth and yield components of maize under three years of experimentation. The growth and yield component values of maize obtained with $T_{2}$ treatment were followed by the treatments $T_{7}$ and $T_{6}$ and both the treatments were statistically at par also. However, control plots experienced the lowest values of growth and yield components of maize (Table 1).

Organic matter applied to preceding maize crop had a positive residual effect on gobhi sarson which improved yield attributes of plants raised in plots that had experienced substitution of nutrients through organic sources in the preceding maize. The values for various growth and yield attributing characters like plant height, primary branches, secondary branches, pod length, seeds/pod and pods/plant statistically differed for residual effects of the various treatments imposed in preceding maize crop in three years under experimentation (Table 2). Control plots recorded the lowest values in all the three years under study. Treatment $\mathrm{T}_{8}$ evinced significantly higher values of all growth and yield attributing characters than the first two best treatments of preceding season i.e., $\mathrm{T}_{9}$ and $\mathrm{T}_{2}$ during all the years under study and on pooled basis. It was followed by statistically same $T_{7}$ and $T_{6}$ treatments. However, values obtained with farmer's practice $\left(\mathrm{T}_{10}\right)$ treatment were also statistically comparable. It may be due to presence of highly persistent material, i,e., cellulose in FYM which required longer time for complete decomposition. Thus nutrients released from FYM for longer period had notable benefits on the succeeding gobhi sarson crop. These results are in the line with those of Panwar (2008).

Maximum maize grain and biological yield of 2409 and $7668 \mathrm{~kg} / \mathrm{ha}$ was recorded in $\mathrm{T}_{9}$ treatment; however, it exhibited statistical parity with $\mathrm{T}_{2}$ treatment which obtained 2136 and 6845 $\mathrm{kg} / \mathrm{ha}$ grain and biological yield of maize crop, respectively. Treatment $T_{9}$ registered 108, 96, 97 and $101 \%$ increase over control and 33, 36, 36 and 35\% increase over farmers practice during three years under study and on pooled basis, respectively. The results of increase in maize yield with application of $\mathrm{Zn}$ in addition to inorganic fertilizers were found in consistent with the findings of Kumwenda et al. (1996). The application of N, P and K fertilizer at optimal level might have made more nutrients available to the maize crop which reflected into higher grain yields by the application of $100 \% \mathrm{RFD}+\mathrm{ZnSO}_{4} 20 \mathrm{~kg} / \mathrm{ha}$ and $100 \% \mathrm{RFD}$ alone. The results are also in consistent with the findings of Abrol et al. (2007). Treatment $\mathrm{T}_{7}$ and $\mathrm{T}_{6}$ produced maize grain yield of 2008 and $1879 \mathrm{~kg} / \mathrm{ha}$, which were about 17 and 22 and 6 and $12 \%$ less than the grain yield values recorded with the treatments $T_{9}$ and $T_{2}$, respectively on pooled basis (Table 3 ). The results are in line with the findings as reported by Pathak and Singh (2002). There was a statistically significant influence on seed and biological yield of gobi sarson as a residual impact of different sources and diverse modes of nutrition applied in previous maize crop in kharif season. Treatment $\mathrm{T}_{8}$ observed significantly higher seed and biological yield of gobi sarson to the tune of 1081 and $5801 \mathrm{~kg} / \mathrm{ha}$ (mean values) and it was also higher than the treatments receiving $100 \%$ RFD alone or with $\mathrm{ZnSO}_{4} 20 \mathrm{~kg} / \mathrm{ha}$ in maize crop. Treatments $\mathrm{T}_{9}$ and $\mathrm{T}_{2}$ registered about 22 and $25 \%$ less seed yield of gobhi sarson than $\mathrm{T}_{8}$; whereas, about 5 and $9 \%$ less seed yield of gobi sarson was observed than farmer's practice $\left(\mathrm{T}_{10}\right)$, respectively. Integration of organic and inorganic; i.e. $\mathrm{T}_{7}$ and $\mathrm{T}_{6}$ registered about 74 and 70 and 87 and $77 \%$ increase of seed and biological yield of gobi sarson over control, respectively. The increase in yield with addition of FYM alone or in combination of inorganic fertilizers may be attributed to the fact that FYM being the store house of nutrients also made release of applied nutrients at its optimum at the same time improved the soil physical conditions (Kumar et al. 2002). FYM application also enhanced population of stimulated nitrogen fixing and phosphate solubilizing microorganisms and thus increased availability of plant nutrients in steady manner (Gaur 1998). The system productivity in 


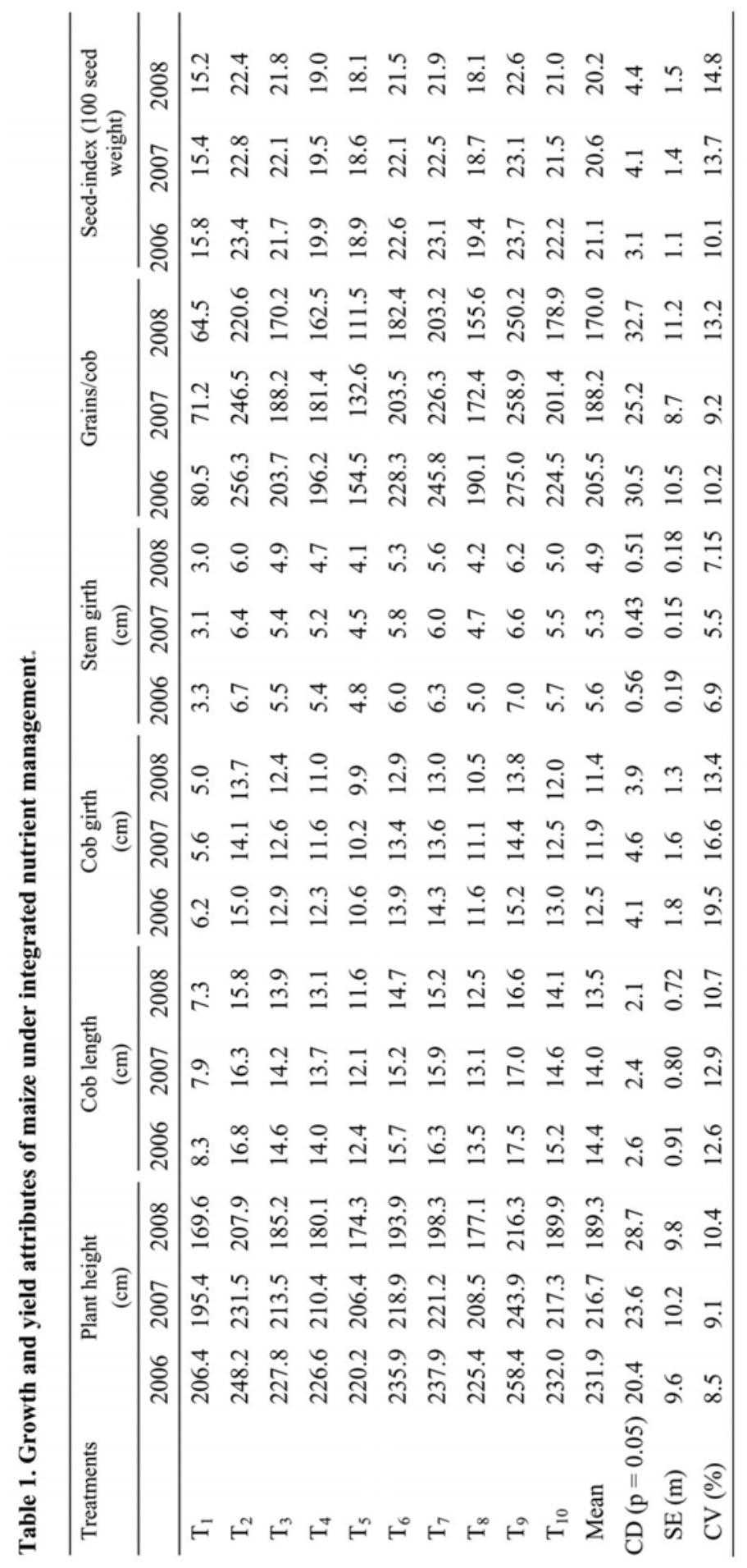




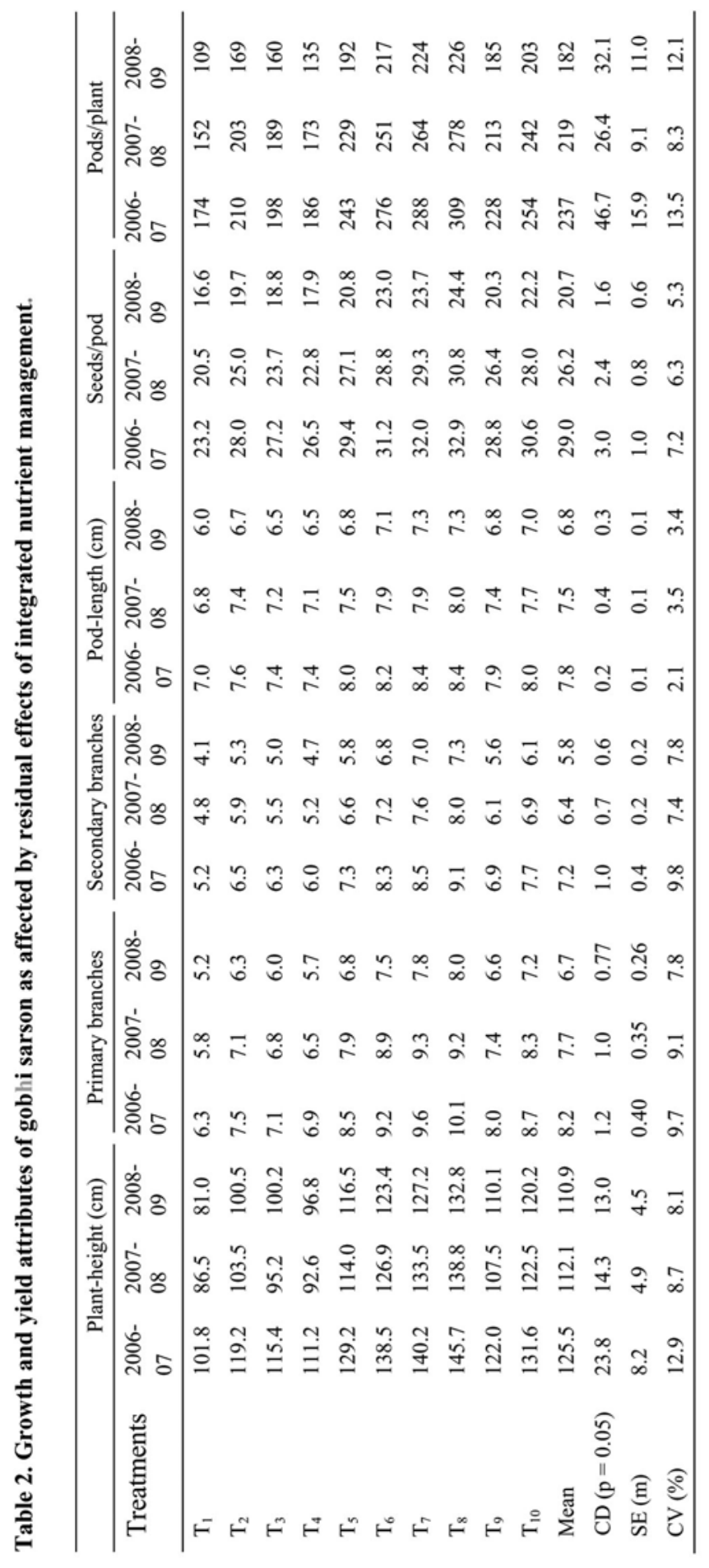




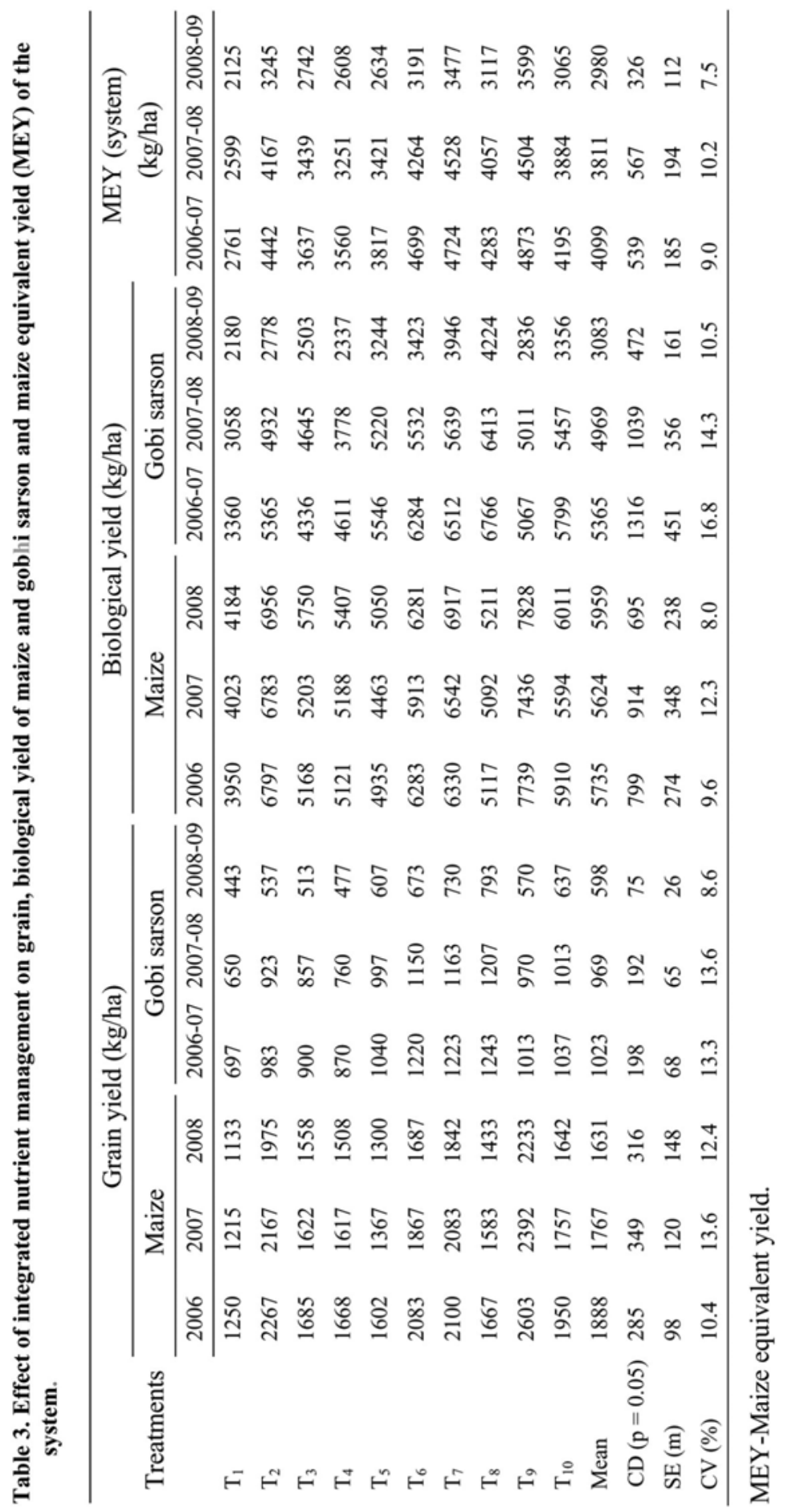


terms of maize equivalent yield (MEY) was significantly influenced by different inorganic and organic fertilizers alone or in combinations. The maximum MEY $(4325 \mathrm{~kg} / \mathrm{ha})$ was obtained from treatment $T_{9}$ followed by MEY values of 4243 and $4051 \mathrm{~kg} / \mathrm{ha}$ recorded with the treatments $\mathrm{T}_{7}$ and $\mathrm{T}_{6}$, respectively. That may be due to the fact that efficiency of inorganic fertilizers increased when these are used in conjunction with organic manures. The results are in line as reported by Yadav 2001. The MEY values in farmer's practice out yielded over $T_{5}, T_{3}$ and $T_{4}$ treatments by about 13 , 14 and $18 \%$, respectively on pooled data basis (Table 3 ). The organic sources enhanced the efficient utilization of the native as well as added fertilizer nutrients, which maintained balance between growth and yield attributes. Thus inclusion of organic sources at either of the level in kharif only enhanced the productivity of the system. The increase in yield of maize-gobhi sarson system was found in consistent with the findings of Abrol et al. (2007) and Panwar (2008).

Effect of $\mathrm{N}$ application through different sources on available $\mathrm{N}$ content and changes in available nitrogen content in experimental soils was studied (Fig. 1). Available nitrogen in soil increased where nitrogen was supplied through integrated approach i.e. organic + inorganic sources. The extent of increase in available $\mathrm{N}$ was highest $(33 \mathrm{~kg} / \mathrm{ha})$ in treatment where $50 \%$ recommended nitrogen was supplied through inorganic source (urea) and rest of the $50 \%$ through organic source (FYM) followed by treatment where 50\% recommended nitrogen was supplied through inorganic source (urea) and rest 50\% through organic source (crop residue). The extent of increase in available $\mathrm{N}$ in this treatment was $26 \mathrm{~kg} / \mathrm{ha}$. In control as well as in treatments where $\mathrm{N}$ was supplied purely through inorganic sources a decrease in available nitrogen was noticed. The increase in available $\mathrm{N}$ in treatments where the $\mathrm{N}$ was supplied through integrated sources could be attributed to the production of carbonic acids during decomposition of organics which mineralize the complex organic substances which in turn contribute to the $\mathrm{N}$ pool. The increase could also be attributed to greater multiplication of soil microbes caused by the addition of organics which mineralize organically bound $\mathrm{N}$ to inorganic form. The results are in the conformity of the findings of Bellakki and Badanur 1997.

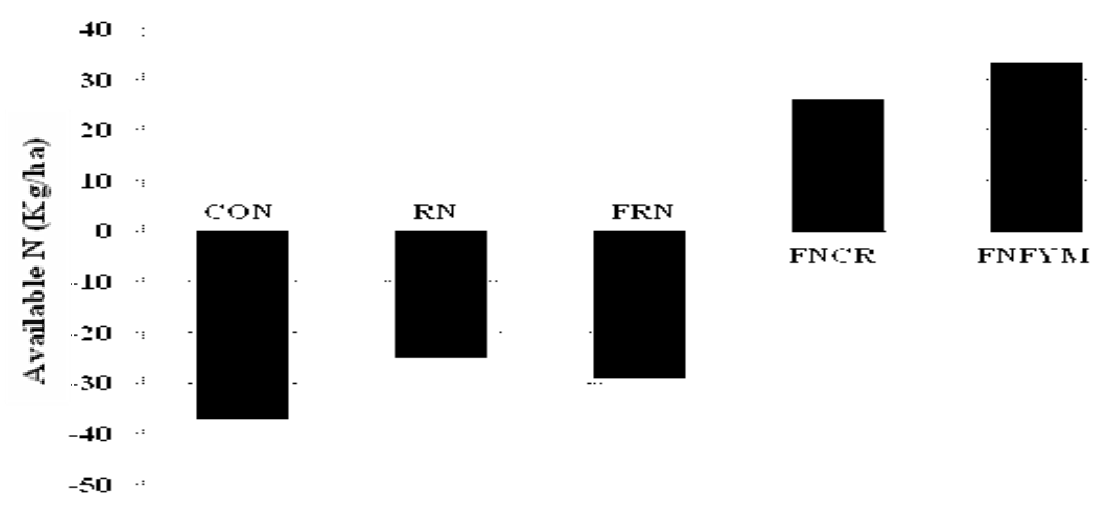

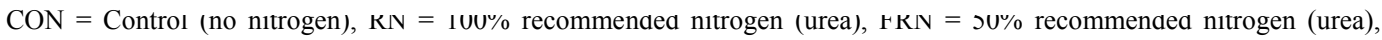
$\mathrm{FNCR}=50 \%$ recommended nitrogen (urea) $+50 \%$ recommended nitrogen through crop residue, $\mathrm{FNFYM}=50 \%$ recommended nitrogen (urea) $+50 \%$ recommended nitrogen through farm yard manure

Fig. 1. Change in soil available nitrogen by repeated applications of nitrogen through different sources.

Statistically highest rain water use efficiency (RWUE) values were recorded in $\mathrm{T}_{9}$ treatment $(3.38 \mathrm{~kg} / \mathrm{ha} / \mathrm{mm})$ in maize crop which was followed by the values obtained in $\mathrm{T}_{2}$ treatment $(2.99$ $\mathrm{kg} / \mathrm{ha} / \mathrm{mm})$. However, the treatments where $50 \% \mathrm{~N}$ was replaced by FYM and crop residue $\left(\mathrm{T}_{7}\right.$ and $\mathrm{T}_{6}$ ) along with $50 \%$ inorganic $\mathrm{N}$ observed statistically similar values of RWUE in maize crop. 
Treatment $T_{8}$ registered statistically highest values of RWUE $(6.07 \mathrm{~kg} / \mathrm{ha} / \mathrm{mm})$ in gobi sarson crop. However, control recorded the least RWUE (1.68 and $3.37 \mathrm{~kg} / \mathrm{ha} / \mathrm{mm})$ values both in maize and gobi sarson crops, respectively. Treatment $T_{7}$ recorded the highest $(8.59 \mathrm{~kg} / \mathrm{ha} / \mathrm{mm})$ RWUE values for maize-gobi sarson system and was followed by statistically similar value obtained in $\mathrm{T}_{6}$ treatment $(8.24 \mathrm{~kg} / \mathrm{ha} / \mathrm{mm})$. The control evinced the lowest RWUE value $(5.05 \mathrm{~kg} / \mathrm{ha} / \mathrm{mm})$ for the system (Fig. 2).

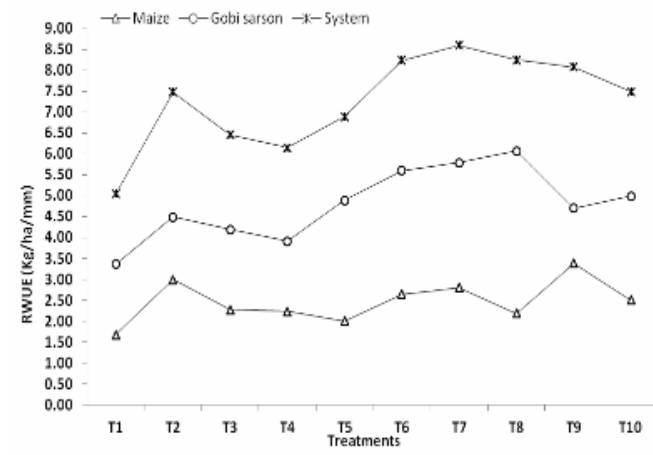

Fig. 2. Rain water use efficiency (RWUE) of maize, gobi sarson and system as affected by integrated nutrient management (mean of 3 years).

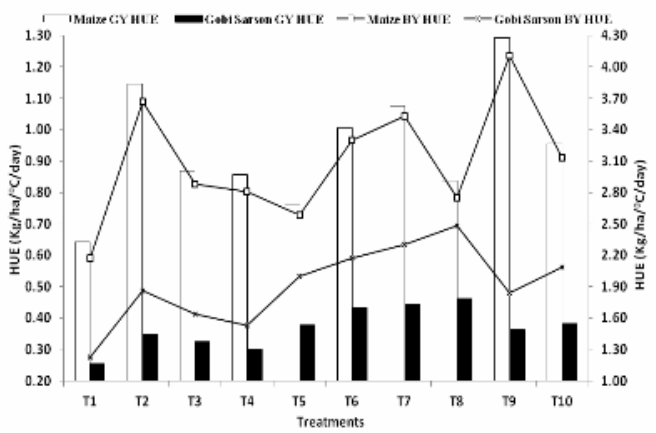

Fig. 3. Heat use efficiency (HUE) of grain and biological yield of maize and gobi sarson crops (pooled data) as affected by integrated nutrient management (mean of three years).

Statistically highest grain yield heat use efficiency (GYHUE) in maize was found to be 1.29 $\mathrm{kg} / \mathrm{ha} /{ }^{0} \mathrm{C} /$ day found in treatment $\mathrm{T}_{9}$, followed by statistically different GYHUE value 1.14 $\mathrm{kg} / \mathrm{ha} /{ }^{0} \mathrm{C} /$ day found in $\mathrm{T}_{2}$ treatment; however the treatment $\mathrm{T}_{2}$ shared statistically same value of GYHUE $\left(1.08 \mathrm{~kg} / \mathrm{ha} /{ }^{0} \mathrm{C} /\right.$ day) with treatment $\mathrm{T}_{7}$ (Fig. 3). Maximum GYHUE value $(0.46$ $\mathrm{kg} / \mathrm{ha} /{ }^{0} \mathrm{C} /$ day) in gobhi sarson crop was found in treatment $\mathrm{T}_{8}$ followed by statistically at par value to the tune of 0.44 and $0.43 \mathrm{~kg} / \mathrm{ha} /{ }^{\circ} \mathrm{C} /$ day in treatments $\mathrm{T}_{7}$ and $\mathrm{T}_{6}$, respectively. The biological yield heat use efficiency (BYHUE) of maize and gobhi sarson crops followed the similar trend. The various treatments of organic and inorganic nutrients significantly affected the dry matter accumulation in maize and gobhi sarson crops due to which significantly different values of GYHUE and BYHUE values of both the crops were obtained.

\section{References}

Abrol V, Sharma V, Sharma P, Khar D, Vittal KPR and KL Sharma 2007. Direct and residual effect of organic and inorganic sources of nutrients on maize (Zea mays)-mustard (Brassica napus) cropping sequence under rainfed conditions. Ind. J. Dry. Agric. Res. Devel. 22: 82-89.

Anonymous 2010. Directorate of Economics and Statistics, Agricultural Statistics at Glance. Department of Agricultural and Cooperation. Ministry of Agriculture, Government of India.

Balakrishanan K and Natarajaratnam N 1986. Heat unit efficiency in pigeonpea. Mad. Agric. J. 73: 101-104.

Bellakki MA and Badanur VP 1997. Long term effect of integrated nutrient management on properties of vertisols under dryland agriculture. J. Ind. Soc. Soil Sci. 45: 438-442.

Gaur AC 1998. Integrated plant nutrient supply system blending organic, bio and chemical sources. (In): Soil-Plant-Microbe Interaction in relation to Integrated Nutrient Management. Kaushik BD (Ed), Division of Microbiology, Indian Agricultural Research Institute, New Delhi. pp. 14-27. 
Jamwal JS 2005. Productivity and economics of maize (Zea mays)-wheat (Triticum aestivum) cropping system under rainfed areas of Jammu. Ind. J. Agron. 50: 110-112.

Kumar A, Thakur KS and Manuja S 2002. Effect of fertilizer levels on promising hybrid maize (Zea mays) under rainfed conditions of HP. Ind. J. Agron. 47: 526-528.

Kumpawat BS 2004. Integrated nutrient management for maize (Zea mays)-Indian mustard (Brassica juncea) cropping system. Ind. J. Agron. 49: 18-21.

Kumwenda JDT, Waddington SR, Snapp SS, Jones RB and Blackie MJ 1996. Soil fertility management research for the maize cropping systems of smallholders in Southern Africa: A review. NGR paper 96102, Mexico, D F: CIMMYT.

Nuttonson MY 1955. Wheat-climate relationships and the use of phenology in ascertaining thermal and photothermal requirements of wheat. American Institute of crop Ecology, Washington DC, pp. 388.

Panwar AS 2008. Effect of integrated nutrient management in maize (Zea mays)-mustard (Brassica compestris var toria) cropping system in mid hills altitude. Ind. J. Agric. Sci. 78: 27-31.

Pathak SK and Singh SN 2002. Effect of integrated nutrient management on growth, yield and economics in maize-wheat cropping system. Ind. J. Agron. 47: 325-332.

Rao VUM, Singh D and Singh R 1999. Heat use efficiency of winter crops in Haryana. J. Agromet. 1: 143148.

Yadav RL 2001. On farm experiments on integrated nutrient management in rice-wheat cropping system. Experim. Agric. 37: 99-113.

(Manuscript received on18 June, 2013; revised on 30 January, 2014) 